\title{
遠赤色光透過抑制フィルムの短期間処理が数種花壇苗の生育・開花に及ぼす影響
}

\author{
土橋 豊 ${ }^{\mathrm{a}}$ \\ 京都府農業総合研究所 621-0806 京都府亀岡市
}

\section{Effects of Short Duration Treatment of Far-red-intercepting Film on the Growth and Flowering of Certain Bedding Plants}

\author{
Yutaka Tsuchihashi ${ }^{\mathrm{a}}$ \\ Kyoto Prefectural Agricultural Research Institute, Kameoka, Kyoto 621-0806
}

\begin{abstract}
The effects of the duration of covering treatment and the period of using a far-red-intercepting film (FR-intercepting film) while raising seedling on the future growth and flowering of certain bedding plants were investigated. The plant heights of scarlet sage (Salvia splendens Sell ex Roem. \& Schult.), cupflower (Nierembergia hippomanica Miers. var. violacea Millan.), Madagascar periwinkle (Catharanthus roseus (L.) G. Don), French marigold (Tagetes patula L.) and pansy (Viola $\times$ wittrockiana Gams) and the flower stalk length of pansy kept under the FR-intercepting film for 3 weeks after potting were significantly shorter than those of the control plants. Flowering of scarlet sage, cupflower and French marigold kept under the FR-intercepting film for 3 weeks after potting was delayed. The plant height of snapdragon (Antirrhinum majus L.) kept under the FR-intercepting film for 4 weeks after potting was significantly shorter than that of the control plants. A decrease in the internode length between the 3rd and 5th nodes was considered the cause of the shorter plant height. These findings indicated that in certain bedding plants (scarlet sage, cupflower, Madagascar periwinkle, French marigold, pansy and snapdragon), covering treatment using the FR-intercepting film for only 3-4 weeks after potting tended to prevent succulent growth.
\end{abstract}

Key Words : length of flower stalk, light quality, plant height, R/FR ratio, succulent growth

キーワード : 花柄長, 光質, 草丈, R/FR 比, 徒長

\section{緒 言}

一般的に花壇苗生産は, 高温条件下の施設内での栽培と なり, 徒長しやすい環境条件であるといえる. 一方, 流通 および販売時のストレスに耐え, 販売時における外見的品 質が高い苗を生産するためには, 草丈や草姿などの生育調 節を行らことは極めて重要である. また, 出荷用トレイに 整然と詰める上でも, 揃いのよいコンパクトな苗づくりが 要求される.

花壇苗生産場面では，これまで成長抑制物質による生育 調節が行われていたが（岸本，1999; Larson, 1985), 品目ご とに登録薬剤が決まって打り，乙か子登録薬剤が少ない現 状にあり, 多数の品目を生産する場合には適正使用が困 難な状況にある。ささらには, 近年の農薬等の化学物質へ の使用削減の傾向から，ますます使用が困難となってきて

2008 年 3 月 10 日 受付. 2008 年 8 月 11 日 受理.

本報告の一部は平成 17 年度園芸学会近畿支部滋賀大会で発表した. E-mail: y-tsuchi@koshien.ac.jp

a 現在 : 甲子園短期大学家政学科 663-8107 西宮市瓦林町
おり，環境制御による生育調節技術の開発が求められてい る (腰岡, 1998).

環境制御による徒長防止技術としては，DIF および光質 制御を利用した生育調節が試みられている（腰岡，1998; Patil ら，2001）。草丈伸長制御を目的とした光質制御のひ とつとして, 赤色光 / 遠赤色光光量子束密度比 (R/FR 比) を変化させた被覆資材の開発と検討が行われ（Cerny ら， 2000; Grindal ら，2000; 村上ら，1995; Rajapakse ら，1999), いずれも R/FR 比が 1 より大きくなる被覆資材を用いると, 草丈の伸長が抑制されたと報告されている.

しかし, 遠赤色光透過抑制フィルムは色素劣化による光質 の変化に対応するために 1 年に 1 回フィルムを交換する必要 があるが，一般に農業用被覆フィルムに比べて割高である. また, 遠赤色光透過抑制フィルムを施設全面に展張すること は，単一品目を生産する施設では例はあるが，生育段階の異 なる多品目を生産する花壇苗生産では実用的ではなく, 例が ない. 遠赤色光透過抑制フィルムの展張面積の低減を図る方 法のひとつとして, 被覆処理による草丈抑制効果が認められ る処理時期と期間にのみ同フィルム下で栽培することで, 処 理期間の短縮化を図ることが考えられる. 
そこで本研究では, 徒長防止効果が認められる遠赤色光 透過抑制フィルムを用い, 代表的な数種花壇苗における鉢 上げ時を起点とした処理時期と期間を検討した。

\section{材料および方法}

実験 1,2 は京都府農業総合研究所・旧花き部（京都府京 田辺市）のポリエステルフィルム（シクスライトクリーン ムテキ, MKVプラテック社製) を外張り展張したハウス 内で, 実験 3, 4 は京都府農業総合研究所（京都府亀岡市） のガラスハウス内で行った. 実験 1,2 では遠赤色光透過抑 制フィルム (有望株, 三井化学プラテック社製, R/FR 比 $=1.43$, 光合成有効放射の光線透過率 $75.8 \%$, 厚さ $0.05 \mathrm{~mm}$ ），実験 3， 4 では遠赤色光透過抑制フィルム（メ ガクール, 三井化学プラテック社製, R/FR 比 $=1.52$, 光合 成有効放射の光線透過率 $74.2 \%$, 厚さ $0.05 \mathrm{~mm}$ ) を供試し, ともに鉢上げ苗の上部から, 高さ $120 \mathrm{~cm}$ の位置に幅 $110 \mathrm{~cm}$ のトンネル状に内張り展張し, 裙面と妻面ともに $45 \mathrm{~cm}$ の 垂れ下げ部と, 下面から $75 \mathrm{~cm}$ の開口部を設けて処理を行っ た. な打，遠赤色光透過抑制フィルムの特性データは製造 会社からの提供により, 両フィルムの R/FR 比の定義波長 域は $600 \sim 700 \mathrm{~nm} / 700 \sim 800 \mathrm{~nm}$ であった. 対照区である 無処理区は，ともに鉢上げ苗上部にフィルムを内張り展張 しない条件下で設けた。

播種は, 実験 $1 ， 2$ ではセル成型苗用トレイ 200 穴 SQ 型 (Land Mark Co. 製，1 セル容量 $12.5 \mathrm{~mL}$ )，実験 3，4 では 288 穴 DEEP 型（Land Mark Co. 製，1 セル容量 $10.0 \mathrm{mL）を}$ 使用し, セル育苗専用培養土（Metromix 350, Grace-Sierra Horticultural Products Co. 製）を充填して行った. 鉢上げは ピートモス, もみ殼くん炭, パーライトを体積比で $7: 2: 1$ の培養土を用い, 基肥として培養土 $1 \mathrm{~L}$ 当たり緩効性被覆 肥料 (ロング 100 日タイプ, チッソ旭肥料製, $\mathrm{N}: \mathrm{P}_{2} \mathrm{O}_{5}: \mathrm{K}_{2} \mathrm{O}=$ $14: 12: 14) 1.5 \mathrm{~g}$, リン酸質肥料 (BM ようりん, 日之出化 学工業製, $\mathrm{N}: \mathrm{P}_{2} \mathrm{O}_{5}: \mathrm{K}_{2} \mathrm{O}=0: 20: 0$ ) $1 \mathrm{~g}$, 石灰質肥料（苦 土石灰，河合石灰工業株式会社製，〈溶性苦土 $10 \sim 15 \%$, 石灰 30 ～35\%） $4.2 \mathrm{~g}$ を施した. 鉢は $7.5 \mathrm{~cm}$ 黒色ポリポッ トを用いた，追肥として複合液体肥料（OKF-3，大塚化学， $\left.\mathrm{N}: \mathrm{P}_{2} \mathrm{O}_{5}: \mathrm{K}_{2} \mathrm{O}=14: 8: 25\right)$ の $500 \sim 1,000$ 倍液を月に 2 回 施した.

統計処理は, 実験 1 では Mann-Whitney のU 検定, 実験 $2 \sim 4$ ではいずれの処理間で有意差があるかを明らかにす るために Bonferroni の多重比較を行った. なお, 実験 2,3 の開花株率は統計処理を行わなかった.

\section{1. 鉢上げから 3 週間の遠赤色光透過抑制フィルムの被覆 が花壇苗の生育に及ぼす影響（実験 1）}

供試植物としてサルビア (Salvia splendens Sell ex Roem. \& Schult.) ‘トーチライト’, ニーレンベルギア (Nierembergia hippomanica Miers. var. violacea Millan.) ‘パープルローブ’, ニチニチソウ（Catharanthus roseus（L.） G. Don）“トロピ カーナブライトアイ’， マリーゴールド (Tagetes patula L.)
‘マーチエロー’の 4 種類を用いた. 2002 年 3 月 27 日に播 種を行い，鉢上げは第 1 表に示す月日に行った.

遠赤色光透過抑制フィルム区 $(+\mathrm{R} / \mathrm{FR})$ と無処理区の 2 処理区を設け, 鉢上げから 3 週間処理した. 処理終了後, 草丈，株径（株の中心部を通る最大幅）を調査し，上位展 開葉の葉緑素濃度（以下，SPAD 值）は葉緑素計（SPAD502 型，ミノルタ社製）を用いて測定した。 なお, ニーレ ンベルギアは葉の形態上，SPAD 值の測定が困難であった ため測定しなかった.いずれの品目とも 1 反復 1 個体とし, 供試個体数（n）は第 1 表に示した。

\section{2. 遠赤色光透過抑制フィルムの処理時期が花壇苗の生育 に及ぼす影響（実験 2）}

実験 1 で使用した 4 種類およびパンジー (Viola $\times$ wittrockiana Gams） ‘イオナパープル’の5 種類を供試した. パン ジーは 2002 年 8 月 14 日に播種を行い, 9 月 6 日に鉢上げ を行った. 処理区として, 鉢上げから 3 週間処理区 $(\mathrm{P}+\mathrm{P} 3)$, 鉢上げ 3 週間後から出荷期まで処理した区 $(\mathrm{P} 3+\mathrm{S})$, 鉢上 ゲから出荷期まで処理した区（P+S）と，対照区として無 処理区の 4 処理区を設けた. 出荷期は開花株率（(開花株数 ／供試個体） $\times 100 ）$ がすべての処理区で $80 \%$ 以上，ニーレ ンベルギアは個体による開花期の変動幅が著しいため $50 \%$ 以上となった日とした (第 2 表). 開花株は 1 花以上が完全 に開花した株とした. 出荷期にすべての供試個体について, 草丈, 株径, ニーレンベルギアを除いた上位展開葉の SPAD 值，開花株率を調査した。 また，パンジーは花柄長と花径 も測定した。 いずれの品目とも 1 反復 1 個体とし，供試個 体数（n）は第 2 表に示した.

\section{3. 遠赤色光透過抑制フィルムの処理期間がパンジー苗の 生育に及ぼす影響（実験 3）}

供試植物としてパンジー ‘イオナパープル’を用いた. 2003 年 8 月 14 日に播種を行い，9 月 10 日に鉢上げを行っ た. 遠赤色光透過抑制フィルムを鉢上げから 1 週間処理区 $(\mathrm{P}+\mathrm{P} 1) ， 2$ 週間処理区 $(\mathrm{P}+\mathrm{P} 2), 3$ 週間処理区 $(\mathrm{P}+\mathrm{P} 3)$, 4 週間処理区 $(\mathrm{P}+\mathrm{P} 4)$, 鉢上げから出荷期まで処理した区 $(\mathrm{P}+\mathrm{S})$ と, 対照区として無処理区の 6 処理区を設けた. 出 荷期はすべての処理区で開花株率が $80 \%$ 以上となった 10 月 28 日とした. 開花株は 1 花以上が完全に開花した株とし た. 出荷期の 10 月 28 日に, 草丈, 株径, 花柄長, 花径, 上位展開葉の SPAD 值, 開花株率を調査した. 1 反復 1 個 体とし, 各処理区 20 個体を供試した.

\section{4. 遠赤色光透過抑制フィルムの処理期間がキンギョソウ 苗の生育に及ぼす影響（実験 4）}

供試植物としてキンギョソウ（Antirrhinum majus L.）“パ レットイエロー’を用いた. 2003 年 9 月 16 日に播種を行 い，10月 17 日に鉢上げを行った. 遠赤色光透過抑制フィ ルム処理は，鉢上げから 3 週間処理区 $(\mathrm{P}+\mathrm{P} 3), 4$ 週間処 理区（P+P4）, 鉢上げから出荷期まで処理した区（P+S） と，対照区として無処理区の 4 処理区を設けた．出荷期は すべての処理区で蕾着色株率が $80 \%$ 以上となった 12 月 10 
日とした. 蕾着色株は花序の大半の蕾が着色した株とした. すべての供試個体について出荷期の 12 月 10 日に, 草丈, 胚軸長, 上肧軸長, 節間長, 蕾着色株率を調査した. 1 反 復 1 個体とし, 各処理区 5 個体を供試した.

\section{結果}

1. 鉢上げから 3 週間の遠赤色光透過抑制フィルムの被覆 が花壇苗の生育に及ぼす影響（実験 1）

結果は第 1 表に示した. 遠赤色光透過抑制フィルムを鉢
上げから 3 週間処理すると，供試したいずれの花壇苗にお いても，無処理区に比べ，草丈が有意に抑制された。 無処 理区に比べ, サルビアで $0.7 \mathrm{~cm}$, ニーレンベルギアで $2.2 \mathrm{~cm}$, ニチニチソウで $0.5 \mathrm{~cm}$, マリーゴールドで $1.5 \mathrm{~cm}$ の草丈抑 制効果が認められた。株径はサルビアとマリーゴールドに おいて有意に減少したが, ニーレンベルギアとニチニチソ ウには有意差はなかった. SPAD 值にはいずれの品目とも 影響がなかった。

第 1 表 遠赤色光透過抑制フィルム処理が花壇苗の鉢上げ 3 週間後の生育に及ぼす影響

\begin{tabular}{|c|c|c|c|c|c|c|c|c|}
\hline 品目名 & 播種日 & 鉢上げ日 & 調査日 & 処理区 & $\mathrm{n}$ & 草丈 ${ }^{\mathrm{z}}$ (cm) & 株径（cm） & SPAD 值 ${ }^{\mathrm{y}}$ \\
\hline サルビア & 3 月 27 日 & 4 月 17 日 & 5 月 8 日 & $\begin{array}{l}\text { 無処理 } \\
+\mathrm{R} / \mathrm{FR}\end{array}$ & 40 & $\begin{array}{l}8.3 \\
7.6 * *\end{array}$ & $\begin{array}{l}13.4 \\
11.3 * *\end{array}$ & $\begin{array}{l}48.8 \\
49.1 \mathrm{NS}\end{array}$ \\
\hline ニーレンベルギア & 3 月 27 日 & 4 月 24 日 & 5 月 15 日 & $\begin{array}{l}\text { 無処理 } \\
+\mathrm{R} / \mathrm{FR}\end{array}$ & 26 & $\begin{array}{l}11.5 \\
9.3 * *\end{array}$ & $\begin{array}{l}7.9 \\
7.5 \mathrm{NS}\end{array}$ & $-^{x}$ \\
\hline ニチニチソウ & 3 月 27 日 & 4 月 24 日 & 5 月 15 日 & $\begin{array}{l}\text { 無処理 } \\
+\mathrm{R} / \mathrm{FR}\end{array}$ & 16 & $\begin{array}{l}4.4 \\
3.9 * *\end{array}$ & $\begin{array}{l}10.3 \\
9.8 \mathrm{NS}\end{array}$ & $\begin{array}{l}43.6 \\
44.7 \mathrm{NS}\end{array}$ \\
\hline マリーゴールド & 3 月 27 日 & 4 月 9 日 & 4 月 30 日 & $\begin{array}{l}\text { 無処理 } \\
+\mathrm{R} / \mathrm{FR}\end{array}$ & 40 & $\begin{array}{l}9.9 \\
8.4 * *\end{array}$ & $\begin{array}{l}14.3 \\
12.8 * *\end{array}$ & $\begin{array}{l}44.7 \\
45.2 \mathrm{NS}\end{array}$ \\
\hline
\end{tabular}

${ }^{\mathrm{z}}$ 同一品目・カラム内で Mann-Whitney の U 検定により，無処理区に対し**は 1\%水準の有意差があり，NS は有意差がないこと を示す

${ }^{\mathrm{y}} \mathrm{SPAD}$ 值は上位展開葉を測定した

x 葉が線形であるため SPAD 值は測定しなかった

第 2 表 遠赤色光透過抑制フィルムの処理時期が花壇苗の出荷期の生育に及ぼす影響

\begin{tabular}{|c|c|c|c|c|c|c|c|c|c|c|c|}
\hline 品目名 & 播種日 & 鉢上げ日 & 調査日 ${ }^{z}$ & 処理区 & $\mathrm{n}$ & $\begin{array}{l}\text { 草丈 }^{y} \\
(\mathrm{~cm})\end{array}$ & $\begin{array}{l}\text { 株径 } \\
(\mathrm{cm})\end{array}$ & $\begin{array}{c}\text { 花柄長 } \\
(\mathrm{cm})\end{array}$ & $\begin{array}{l}\text { 花径 } \\
(\mathrm{cm})\end{array}$ & SPAD 值 ${ }^{\mathrm{x}}$ & $\begin{array}{c}\text { 開花株率 } \mathrm{v} \\
(\%)\end{array}$ \\
\hline サルビア & 3 月 27 日 & 4 月 17 日 & 5 月 29 日 & $\begin{array}{l}\text { 無処理 } \\
\mathrm{P}+\mathrm{P} 3 \\
\mathrm{P} 3+\mathrm{S} \\
\mathrm{P}+\mathrm{S}\end{array}$ & 20 & $\begin{array}{l}20.2 \mathrm{a} \\
16.4 \mathrm{~b} \\
17.0 \mathrm{~b} \\
12.8 \mathrm{c}\end{array}$ & $\begin{array}{l}11.9 \mathrm{a} \\
12.2 \mathrm{a} \\
12.1 \mathrm{a} \\
11.7 \mathrm{a}\end{array}$ & $\begin{array}{l}- \\
- \\
-\end{array}$ & $\begin{array}{l}- \\
- \\
-\end{array}$ & $\begin{array}{l}42.1 \mathrm{~b} \\
42.2 \mathrm{~b} \\
44.8 \mathrm{~b} \\
46.8 \mathrm{a}\end{array}$ & $\begin{array}{r}100.0 \\
95.0 \\
95.0 \\
70.0\end{array}$ \\
\hline ニーレンベルギア & 3 月 27 日 & 4 月 24 日 & 6 月 10 日 & $\begin{array}{l}\text { 無処理 } \\
\mathrm{P}+\mathrm{P} 3 \\
\mathrm{P} 3+\mathrm{S} \\
\mathrm{P}+\mathrm{S}\end{array}$ & 13 & $\begin{array}{l}21.6 \mathrm{a} \\
19.2 \mathrm{~b} \\
21.2 \mathrm{ab} \\
19.9 \mathrm{ab}\end{array}$ & $\begin{array}{l}18.5 \mathrm{a} \\
15.8 \mathrm{ab} \\
12.2 \mathrm{~b} \\
12.8 \mathrm{~b}\end{array}$ & $\begin{array}{l}- \\
- \\
-\end{array}$ & $\begin{array}{l}- \\
- \\
-\end{array}$ & $\begin{array}{l}\text { - }^{\mathrm{w}} \\
- \\
-\end{array}$ & $\begin{array}{l}76.9 \\
53.8 \\
61.5 \\
61.5 \\
\end{array}$ \\
\hline ニチニチソウ & 3 月 27 日 & 4 月 24 日 & 6 月 10 日 & $\begin{array}{l}\text { 無処理 } \\
\mathrm{P}+\mathrm{P} 3 \\
\mathrm{P} 3+\mathrm{S} \\
\mathrm{P}+\mathrm{S}\end{array}$ & 8 & $\begin{array}{l}13.1 \mathrm{a} \\
11.3 \mathrm{~b} \\
11.6 \mathrm{~b} \\
11.6 \mathrm{~b}\end{array}$ & $\begin{array}{l}13.6 \mathrm{a} \\
13.3 \mathrm{a} \\
13.1 \mathrm{a} \\
13.1 \mathrm{a}\end{array}$ & $\begin{array}{l}- \\
- \\
-\end{array}$ & $\begin{array}{l}- \\
- \\
-\end{array}$ & $\begin{array}{l}54.2 \mathrm{a} \\
53.1 \mathrm{a} \\
53.7 \mathrm{a} \\
54.8 \mathrm{a}\end{array}$ & $\begin{array}{r}87.5 \\
100.0 \\
87.5 \\
87.5\end{array}$ \\
\hline マリーゴールド & 3 月 27 日 & 4 月 9 日 & 5 月 13 日 & $\begin{array}{l}\text { 無処理 } \\
\mathrm{P}+\mathrm{P} 3 \\
\mathrm{P} 3+\mathrm{S} \\
\mathrm{P}+\mathrm{S}\end{array}$ & 20 & $\begin{array}{l}15.5 \mathrm{a} \\
13.5 \mathrm{~b} \\
14.7 \mathrm{a} \\
13.4 \mathrm{~b}\end{array}$ & $\begin{array}{l}15.3 \mathrm{a} \\
13.7 \mathrm{~b} \\
14.7 \mathrm{~b} \\
15.0 \mathrm{a}\end{array}$ & $\begin{array}{l}- \\
- \\
-\end{array}$ & $\begin{array}{l}- \\
- \\
-\end{array}$ & $\begin{array}{l}46.9 \mathrm{~b} \\
46.0 \mathrm{~b} \\
47.2 \mathrm{~b} \\
48.8 \mathrm{a}\end{array}$ & $\begin{array}{r}100.0 \\
85.0 \\
100.0 \\
85.0\end{array}$ \\
\hline パンジー & 8 月 14 日 & 9 月 6 日 & 10 月 30 日 & $\begin{array}{l}\text { 無処理 } \\
P+P 3 \\
P 3+S \\
P+S\end{array}$ & 10 & $\begin{array}{l}14.7 \mathrm{ab} \\
13.1 \mathrm{~b} \\
15.9 \mathrm{a} \\
15.0 \mathrm{a}\end{array}$ & $\begin{array}{l}13.8 \mathrm{a} \\
12.1 \mathrm{a} \\
12.1 \mathrm{a} \\
13.6 \mathrm{a}\end{array}$ & $\begin{array}{c}9.0 \mathrm{ab} \\
7.2 \mathrm{~b} \\
10.1 \mathrm{a} \\
8.5 \mathrm{~b}\end{array}$ & $\begin{array}{l}6.5 \mathrm{a} \\
6.2 \mathrm{a} \\
6.6 \mathrm{a} \\
6.3 \mathrm{a}\end{array}$ & $\begin{array}{l}41.3 \mathrm{a} \\
44.1 \mathrm{a} \\
44.1 \mathrm{a} \\
43.4 \mathrm{a}\end{array}$ & $\begin{array}{r}90.0 \\
80.0 \\
90.0 \\
100.0\end{array}$ \\
\hline
\end{tabular}

\footnotetext{
$\mathrm{z}$ 調査は出荷期（開花株率が $80 \%$ 以上，ニーレンベルギアのみ開花株率 $50 \%$ 以上）に行った

$\mathrm{y}$ 同一品目・カラム内の異英文字間で $5 \%$ 水準の有意差があることを示す（Bonferroni の多重比較）

${ }^{\mathrm{x}} \mathrm{SPAD}$ 值は上位展開葉を測定した

w葉が線形であるため SPAD 值は測定しなかった

$\mathrm{v}$ (開花株数 $/$ 供試個体数 $) \times 100$
} 


\section{2. 遠赤色光透過抑制フィルムの処理時期が花壇苗の生育 に及ぼす影響（実験 2)}

結果は第 2 表に示した。 サルビアにおいて，いずれの処 理区ともに無処理区に比べ有意に草丈が抑制され, P $+\mathrm{S}$ 区 で $7.4 \mathrm{~cm}$, 次いで $\mathrm{P}+\mathrm{P} 3$ 区で $3.8 \mathrm{~cm}, \mathrm{P} 3+\mathrm{S}$ 区で $3.2 \mathrm{~cm}$ 草 丈が短くなった. $\mathrm{P}+\mathrm{S}$ 区に执いて草丈が最も低くなったの は，花序部が立ち上がらなかったことに起因していた．株 径には影響が認められず，SPAD 值は無処理区に対し P $+\mathrm{S}$ 区の久で有意に増加した。 また，開花株率は無処理区に対 し, $\mathrm{P}+\mathrm{S}$ 区の久著しく低下した.

ニーレンベルギアに括いては，無処理区に比べて P + P3 区の久で有意に草丈が抑制された $(2.4 \mathrm{~cm})$ ，また，無処理 区に対し，株径は P3 + S 区拈よび P + S 区に打いて有意に 減少した．開花株率はいずれの処理区とも無処理区に対し て低下し，P+P3 区で最も低下した。

ニチニチソウにおいては, 無処理区に比べていずれの処 理区とも有意に草丈が抑制された。株径，SPAD 值には影 響が認められなかった．開花株率はP+P3 区で無処理区に 対して増加した。

マリーゴールドにおいては, 無処理区に比べて, P + P3
区（2.0 cm）と P + S 区（2.1 cm）で有意に草丈が抑制され た (第 1 図).一方，株径については無処理区に対し，P+P3 区と $\mathrm{P} 3+\mathrm{S}$ 区で有意に減少した。また，SPAD 值は無処理 区に比べ, $\mathrm{P}+\mathrm{S}$ 区で有意に増加した．開花株率は $\mathrm{P}+\mathrm{P} 3$ 区 と $\mathrm{P}+\mathrm{S}$ 区で低下した.

パンジーに执いては，草丈が無処理区に比べ，P + P3 区 $(1.6 \mathrm{~cm})$ で抑制される傾向が認められたが，有意な差では なかった. 花柄長は無処理区に比べ, P + P3 区 $(1.8 \mathrm{~cm})$ と $\mathrm{P}+\mathrm{S}$ 区（0.5 cm）で減少する傾向が認められたが，有意な 差ではなかった，株径，花径，SPAD 值には影響が認めら れなかった. 開花株率には一定の傾向が認められなかった.

3. 遠赤色光透過抑制フィルムの処理期間がパンジー苗の 生育に及ぼす影響（実験 3）

結果は第 3 表に示した。草丈抢よび花柄長は，鉢上げか ら 3 週間（P+P3 区），4 週間（P+P4区），拈よび出荷期 $(\mathrm{P}+\mathrm{S}$ 区) まで遠赤色光透過抑制フィルム被覆処理を行う ことで，無処理区に比べて有意に抑制された．SPAD值は， P + P4 区に扔いて無処理区に比べ有意に増加した。一方, 株径, 花径, 開花株率は，遠赤色光透過抑制フィルム被覆 処理による影響は認められなかった。

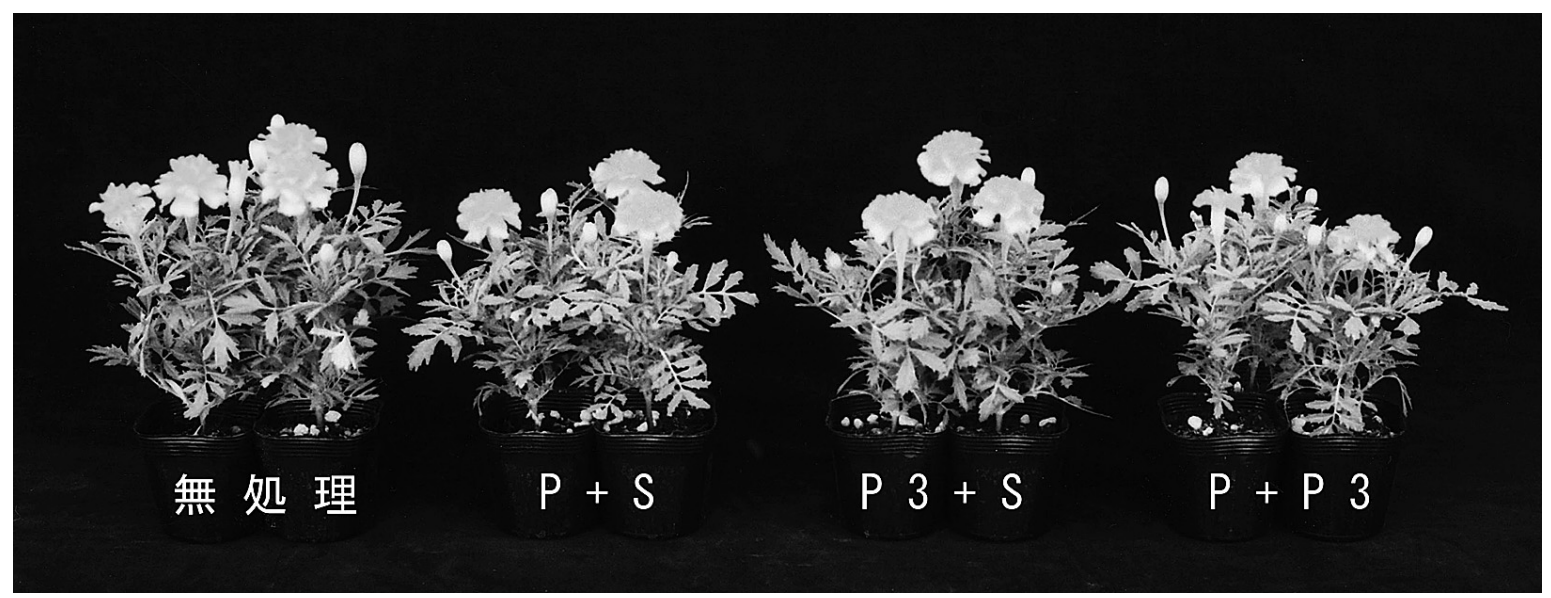

第 1 図 遠赤色光透過抑制フィルムがマリーゴールド ‘マーチエロー’の草姿に及ぼす影響（2002 年 5 月 13 日撮影）

第 3 表＼cjkstart遠赤色光透過抑制フィルムの処理期間がパンジー‘イオナパープル’の生育に及ぼす影響 z

\begin{tabular}{|c|c|c|c|c|c|c|}
\hline 処理区 & $\begin{array}{l}\text { 草丈 }{ }^{y} \\
(\mathrm{~cm})\end{array}$ & $\begin{array}{l}\text { 株径 } \\
(\mathrm{cm})\end{array}$ & 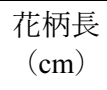 & $\begin{array}{l}\text { 花径 } \\
(\mathrm{cm})\end{array}$ & SPAD 值 ${ }^{x}$ & $\begin{array}{c}\text { 開花株率 }^{\mathrm{w}} \\
(\%)\end{array}$ \\
\hline 無処理 & $19.9 \mathrm{a}$ & $16.4 \mathrm{a}$ & $13.8 \mathrm{a}$ & $6.6 \mathrm{a}$ & $51.2 \mathrm{~b}$ & 90.0 \\
\hline $\mathrm{P}+\mathrm{P} 1$ & $20.9 \mathrm{a}$ & $16.1 \mathrm{a}$ & $13.5 \mathrm{a}$ & $6.2 \mathrm{a}$ & $50.9 \mathrm{~b}$ & 85.0 \\
\hline $\mathrm{P}+\mathrm{P} 2$ & $20.4 \mathrm{a}$ & $16.4 \mathrm{a}$ & $13.9 \mathrm{a}$ & $6.6 \mathrm{a}$ & $51.3 \mathrm{ab}$ & 80.0 \\
\hline $\mathrm{P}+\mathrm{P} 3$ & $17.6 \mathrm{~b}$ & $15.2 \mathrm{a}$ & $11.7 \mathrm{~b}$ & $6.3 \mathrm{a}$ & $50.3 \mathrm{~b}$ & 95.0 \\
\hline $\mathrm{P}+\mathrm{P} 4$ & $17.7 \mathrm{~b}$ & $16.7 \mathrm{a}$ & $11.5 \mathrm{~b}$ & $6.4 \mathrm{a}$ & $54.8 \mathrm{a}$ & 90.0 \\
\hline $\mathrm{P}+\mathrm{S}$ & $17.6 \mathrm{~b}$ & $17.2 \mathrm{a}$ & $11.6 \mathrm{~b}$ & $6.6 \mathrm{a}$ & $51.1 \mathrm{~b}$ & 90.0 \\
\hline
\end{tabular}

${ }^{\mathrm{z}} 2003$ 年 8 月 13 日播種，9月 10 日鉢上げ，10月 28 日調査（開花株率が $80 \%$ 以上となった出荷期）

$\mathrm{y}$ 同一カラム内の異英文字間で 5\%水準の有意差があることを示す（Bonferroni の多重比較， $\mathrm{n}=20$ )

${ }^{x}$ SPAD 值は上位展開葉を測定した

${ }^{\mathrm{w}}$ (開花株数 /供試個体数) $\times 100$ 
第 4 表 遠赤色光透過抑制フィルムの処理期間がキンギョソウ“パレットレッド’の草丈，肧軸長，上胚軸長，節間長扣よび蕾 着色株率に及ぼす影響z

\begin{tabular}{|c|c|c|c|c|c|c|c|c|c|c|}
\hline 処理区 & $\begin{array}{l}\text { 草丈 }{ }^{y} \\
(\mathrm{~cm})\end{array}$ & $\begin{array}{l}\text { 胚軸長 } \\
(\mathrm{cm})\end{array}$ & $\begin{array}{c}\text { 上胚軸長 } \\
(\mathrm{cm})\end{array}$ & $\begin{array}{c}\text { 第 } 1 \text { 節間長 } \\
(\mathrm{cm}) \\
(\mathrm{cm})\end{array}$ & $\begin{array}{c}\text { 第 } 2 \text { 節間長 } \\
(\mathrm{cm})\end{array}$ & $\begin{array}{c}\text { 第 } 3 \text { 節間長 } \\
(\mathrm{cm})\end{array}$ & $\begin{array}{c}\text { 第 } 4 \text { 節間長 } \\
(\mathrm{cm})\end{array}$ & $\begin{array}{c}\text { 第 } 5 \text { 節間長 } \\
(\mathrm{cm})\end{array}$ & $\begin{array}{c}\text { 第 } 6 \text { 節間長 } \\
(\mathrm{cm})\end{array}$ & $\begin{array}{c}\text { 蕾着色株率 } \mathrm{x} \\
(\%)\end{array}$ \\
\hline 無処理 & $21.7 \mathrm{a}$ & $1.0 \mathrm{a}$ & $1.3 \mathrm{a}$ & $2.3 \mathrm{a}$ & $2.7 \mathrm{a}$ & $2.8 \mathrm{a}$ & $2.7 \mathrm{a}$ & $2.1 \mathrm{a}$ & $2.3 \mathrm{a}$ & 80 \\
\hline$P+P 3$ & $20.6 \mathrm{a}$ & $0.9 \mathrm{a}$ & $1.5 \mathrm{a}$ & $2.2 \mathrm{a}$ & $2.6 \mathrm{a}$ & $2.8 \mathrm{a}$ & $2.4 \mathrm{ab}$ & $1.9 \mathrm{ab}$ & $2.2 \mathrm{a}$ & 80 \\
\hline $\mathrm{P}+\mathrm{P} 4$ & $17.2 \mathrm{~b}$ & $1.0 \mathrm{a}$ & $1.3 \mathrm{a}$ & $1.9 \mathrm{a}$ & $2.3 \mathrm{a}$ & $2.4 \mathrm{~b}$ & $2.2 \mathrm{~b}$ & $1.5 \mathrm{~b}$ & $1.7 \mathrm{a}$ & 80 \\
\hline $\mathrm{P}+\mathrm{S}$ & $21.8 \mathrm{a}$ & $0.9 \mathrm{a}$ & $1.7 \mathrm{a}$ & $2.2 \mathrm{a}$ & $2.6 \mathrm{a}$ & $3.0 \mathrm{a}$ & $2.7 \mathrm{a}$ & $2.3 \mathrm{a}$ & $2.4 \mathrm{a}$ & 80 \\
\hline
\end{tabular}

${ }^{\mathrm{z}} 2003$ 年 9 月 16 日播種， 10 月 17 日鉢上げ，12月 10 日調査（開花株率が $80 \%$ 以上となった出荷期）

$\mathrm{y}$ 同一カラム内の異英文字間で 5\%水準の有意差があることを示す（Bonferroni の多重比較, $\mathrm{n}=5$ ）

$\mathrm{x}$ (蕾着色株数 /供試個体数 $) \times 100$

\section{4. 遠赤色光透過抑制フィルムの処理期間がキンギョソウ 苗の生育に及ぼす影響（実験 4）}

結果は第 4 表に示した. 遠赤色光透過抑制フィルム被覆 処理により, 草丈が P + P4 区に拈いて無処理区に対し有意 に抑制された $(4.5 \mathrm{~cm})$. 肧軸長と上胚軸長は，処理による 影響は認められなかった。 一方, 各節間長は, 第 3 節間長 から第 5 節間長において無処理区に比べ P + P4 区で有意に 抑制されることが認められた。 また, 蕾着色株率には影響 が認められなかった。

\section{考察}

本研究では, 代表的な花壇苗生産に打ける遠赤色光透過 抑制フィルムを用いた草丈伸長抑制を行ら際の，鉢上げ時 を起点とした処理時期と期間を明らかにした.

遠赤色光透過抑制フィルムの光合成有効光量子束密度 （PPFD）は，フィルムが無い場合と比べ約 34\%減少するこ とが報告されている（Yamazaki ら，2000）。本研究で用いた 2 種類の遠赤色光透過抑制フィルムは, と正に光合成有効放 射の光線透過率が $75 \%$ 前後であり, PPFD が無処理区に対 し減少していることは明らかである，堀田・林（1998）は， 遠赤色光透過抑制フィルム区，抢よび遠赤色光透過抑制 フィルムと光線透過率がほぼ同じ白寒冷紗区と, 無被覆区 の 3 区を設け，遠赤色光透過抑制フィルム区に拈いてトマ ト，キュウリ，ナスの草丈が，寒冷紗区より抑制されるこ とを報告している. このことは，草丈伸長抑制効果が，主 としてR/FR 比の違いに起因していることを示唆している.

遠赤色光透過抑制フィルムを用いた草丈伸長抑制に関し ては，花壇苗としてパンジー（鷹見ら，1997）, ペチュニア (Kubota 5, 2000; Patil ら, 2001), サルビア属 3 種 (Wilson・ Rajapaske, 2001），鉢物としてポインセチア（Clifford ら, 2004)，フクシア（Patilら，2001）などで効果があることが 報告されている。 また，同じょらな環境条件下で苗生産さ れる野菜苗でも, トマト, キュウリ, ナス (堀田・林, 1998), キュウリ，トマト（伏原・三井，1998），キャベッ，八クサ イ（横山ら，2000），チンゲンサイ（林田ら，2001），エン ドウ（Patil ら，2001）などで同様の効果が認められている. さらに, 須藤（1996）は，遠赤色透過抑制アクリル樹脂板 を用い, インパチエンス，サルビア，マリーゴールド，パ
ンジーキャベッのセル成型苗に抢いて同様の効果を報告 している.

実験 1 に打いて，遠赤色光透過抑制フィルムを鉢上げか ら 3 週間処理すると, 供試したすべての花壇苗（サルビア, ニーレンベルギア，ニチニチソウ，マリーゴールド）に特 いて草丈が有意に抑制され (第 1 表), 代表的な花壇苗品目 に対する遠赤色光透過抑制フィルムの効果を確認すること ができた。一方，多くの品目を異なる生育ステージで栽培 する必要がある花壇苗生産において遠赤色光透過抑制フィ ルムを施設の全面に展張することは適切ではなく，実験 2 以降で適切な処理時期と期間について検討した.

実験 2 の結果から，サルビアでは，草丈が抑制され，か つ開花遅延を引き起こさない処理としては，鉢上げから 3 週間処理（P+P3 区） と鉢上げ 3 週間後から出荷期まで処 理した区（P3+S 区）であった（第 2 表）。一般に，花壇苗 生産では苗が大きくなるにつれて鉢の間隔を広げていくこ とから，少ない面積で処理ができる鉢上げから 3 週間処理 が適切であると考えられる。鉢上げから出荷期まで処理を 続けると開花株率が低下し，開花遅延が起こることから， 処理期間を厳密にする必要がある. Wilson・Rajapakse (2001) によると，3 種のサルビアを供試したところ，いずれも遠 赤色光透過抑制フィルム被覆処理を行って 6 週間栽培する と，草丈が有意に抑制されたと述べている．また，開花期 には有意な差は認められなかったものの，対照区に比べて 1.6 日遅れることを報告しており,この結果は本研究とほぼ 一致している.

ニーレンベルギアでは，鉢上げから 3 週間処理すると草 丈が有意に抑制されたが，同処理により無処理区に比べ開 花株率が 23.1\%低下し，開花遅延の傾向が認められた（第 2 表). 遠赤色光透過抑制フィルムを用いて徒長防止を行う には，開花が遅れることを前提として出荷計画を図る必要 がある。

ニチニチソウ扎よびマリーゴールドでは，鉢上げから 3 週間処理で有意な草丈抑制が認められた（第 2 表）。処理期 間の短縮化を考慮すると，同被覆処理が最も適していると 考えられる。な拈，マリーゴールドでは鉢上げから 3 週間 を含む被覆処理（P+P3，P+S）により開花株率が無処理 区に比べ 15\%低下し，やや開花が遅延する傾向が認められ 
た（第 2 表）。対に，ニチニチソウでは鉢上げから 3 週間 処理（P+P3）により開花株率が 12.5\%増加し, やや開花 促進される傾向があった（第 2 表）。、リーゴールド，二チ ニチソウともに，処理による開花への影響を前提として出 荷計画を立てる必要がある。

パンジーでは，実験 2 に打いては，草丈および花柄長が 無処理区と比較して有意な差が認められる処理区はなかっ た（第 2 表），一方，実験 3 に打いては，鉢上げから 3 週間 以上処理した区に招いて, 草丈および花柄長が無処理区に 対して有意に抑制された (第 3 表). 実験 2 と実験 3 に打い て，遠赤色光透過抑制フィルムによる生育反応が異なって いたが，処理による効果が著しかった実験 3 の無処理区の 草丈が $19.9 \mathrm{~cm}$ と, 実験 2 の無処理区の草丈 $14.7 \mathrm{~cm}$ に比べ て高いことから, 徒長気味に生育している方が遠赤色光透 過抑制フィルムの効果が高い可能性がある. また, 花柄長 は出荷時および販売時の品質低下に大きく関与しており， 実験 3 の結果から同処理により花柄長が短くなることは, 品質面に抢いて重要である，開花株率に関しては，実験 2, 3 の結果からは一定の傾向は認められなかった。 これらの ことから, パンジーに拈いては，鉢上げから 3 週間処理が， 草丈の抑制に最も効果的であると考えられた.

キンギョソウでは，鉢上げから4週間処理を行うと，草 丈が無処理区に対して有意に抑制された（第 4 表）. 肧軸か ら第 6 節間長までの合計を草丈から差し引くと, 無処理区 では $4.5 \mathrm{~cm}$ であるのに対し，P+P3 区では $4.1 \mathrm{~cm}, \mathrm{P}+\mathrm{P} 4$ 区では $2.9 \mathrm{~cm}, \mathrm{P}+\mathrm{S}$ 区では $4.0 \mathrm{~cm}$ となった。従って, 鉢 上げから 4 週間処理したことによる草丈の抑制は第 $3 \sim 5$ 節間長の減少とともに，花序部を含む第 6 節間より上位部 が短くなったことも要因のひとつである。な抏，鉢上げか ら出荷期まで被覆処理を継続して行うと, 草丈の伸長抑制 が認められず，キンギョソウに対して遠赤色光透過抑制 フィルムの効果が現れる時期は, 他の品目と比較して限定 的であった.

以上の結果，サルビア，ニーレンベルギア，ニチニチソ ウ，マリーゴールド，パンジーにおいては，鉢上げから 3 週間処理，キンギョソウにおいては鉢上げから4 週間の短 期間処理により徒長防止効果が認められる. なお, サルビ アは鉢上げから出荷期まで，ニーレンベルギアはすべての 処理で，マリーゴールドは鉢上げから 3 週間を含む処理に より開花遅延を起こすことが，反対に，ニチニチソウでは 鉢上げから 3 週間処理により開花促進されることが示唆さ れ，遠赤色光透過抑制フィルム処理による開花への影響を 前提とした出荷計画を立てる必要がある，また，栽培期後 半の日照量が減少する秋期出荷パンジーや冬期出荷キン ギョソウに扎いては，遠赤色光透過抑制フィルムの効果が 見られないか，または被覆処理が長くなると，草丈抑制効 果が消失することがある. 従って，今後は日照量が減少す る時期に打ける遠赤色光透過抑制フィルム被覆処理による 草丈抑制効果と, R/FR 比が開花に及ぼす影響についてさら
に検討するとともに，Rajapakse・Cerny（2000）も指摘す るように, R/FR 比による草丈制御は種類や品種により効果 に違いがあることから，多数ある花壇苗の種類毎に効果を 確認する必要がある.

一方，株径に関しては，鉢上げから 3 週間処理により， サルビア（実験 1），マリーゴールド（実験 1，2）におい て，無処理区に対して有意に減少した。株径がポット直径 より小さくなると花壇苗の商品性が低下するが，本実験に おいてはサルビアおよびマリーゴールドの出荷期の株径が ポットの直径 $7.5 \mathrm{~cm}$ より小さくなることはなく (第 2 表), 遠赤色光透過抑制フィルム処理により花壇苗の商品性は低 下しないと考えられる。

\section{摘 要}

数種類の花壇苗において，育苗期間中の遠赤色光透過抑 制フィルムの処理時期および処理期間が生育・開花に及ぼ す影響について検討した．遠赤色光透過抑制フィルム被覆 処理を鉢上げから 3 週間行うと, サルビア, ニーレンベル ギア，ニチニチソウ，マリーゴールド，パンジーでは無処 理区に比べて草丈が有意に抑制され，パンジーでは花柄長 が有意に減少することが明らかになった。な抏，サルビア， ニーレンベルギア，マリーゴールドでは，鉢上げから 3 週 間処理により, 開花が遅延する傾向が認められた。 また, キンギョソウでは遠赤色光透過抑制フィルムを鉢上げから 4 週間被覆すると, 草丈が無処理区に比べ有意に抑制され, このことは第 3 節間より上の節間長の減少に起因すると考 えられた。

謝 辞 本研究を遂行するにあたり，京都府農業総合研 究所花き部の方々から多大なるご指導，ご援助を頂きまし た. ここに記して厚く感謝いたします。

\section{引用文献}

Cerny, T. A., N. C. Rajapakse and J. R. Rieck. 2000. Description of light quality parameters in controlled environment research. BIOTRONICS 29: 17-21.

Clifford, S. C., E. S. Runkle, F. A. Langton, A. Mead, S. A. Foster, S. Pearson and R. D. Heins. 2004. Height control of Poinsettia using photoselective filters. HortScience 39: 383-387.

伏原 肇・三井寿一. 1998. 被覆資材による赤色光／遠赤 色光比の制御がキュウリやトマトの苗の生育に及ぼす 影響. 九農研. 60: 169 .

Grindal, G., L. M. Mortensen and R. Moe. 2000. Manipulation of daylight spectre for growth control. p. 75-82. In: E. Strømme (ed.) Advances in Floriculture Research. Agricultural University of Norway. Report No. 6.

林田達也・柴戸靖志・浜地勇次 - 大和陽一 - 山崎弘子 ・ 三浦周行. 2001. 赤色光 / 遠赤色光比の異なる光環境 が高温条件下で生育するチンゲンサイ成型苗の伸長に 
及ぼす影響. 園学雑. 70: 774-776.

堀田行敏・林 悟朗. 1998. 赤色光 / 遠赤色光比を調節し たフィルム被覆下でのトマト, キュウリ及びナスの生 育反応. 愛知農総試研報. 30: 115-120.

岸本真幸. 1999. 花壇苗の生産技術. わい化剤による草丈 コントロール. p. 839-843. 農業技術大系花卉編5. 農 文協. 東京.

腰岡政二. 1998. 環境制御による花きの生育調節. 農及園. 73: 283-288.

Kubota, S., T. Yamato, T. Hisamatsu, S. Esaki, R. Oi, M. S. Roh and M. Koshioka. 2000. Effects of red-and far-red-rich spectral treatments and diurnal temperature alternation on the growth and development of Petunia. J. Japan. Soc. Hort. Sci. 69: 403-409.

Larson, R. A. 1985. Growth regulators in floriculture. p. 399481. In: J. Janick (ed.). Hort. Rev. vol. 7. AVI Publishing, Westport, Conn.

村上克介 - 中村 立 - 児玉邦雄 - 崔 海信 - 清田 信 相賀一郎. 1995 . 自然光の赤色光 / 遠赤色光光量子束 比を変化させる植物成長制御用被覆資材の開発 (1) 被 覆資材の設計. 生環調. 33: 31-36.

Patil, G. G., R. Oi, A. Gissinger and R. Moe. 2001. Plant morphology is affected by light quality selective plastic films and alternating day and night temperature. Gartenbau- wissenschaft 66: 53-60.

Rajapakse, N. C. and T. Cerny. 2000. Photoselective covers for plant growth regulation. FlowerTECH 3: 32-35.

Rajapakse, N. C., R. E. Young, M. J. mcMahon and R. Oi. 1999. Plant height control by photoselective filters: Current status and future prospects. HortTechnology 9: 618-624.

須藤憲一. 1996. 赤色光 / 遠赤色光光量子束比を変化させ た被覆資材下における七ル成形苗の生育. 園学雑. 65 (別1) : 444-445.

鷹見敏彦・腰岡政二・齊藤 哲・江崎定幸・竹村康男. 1997. 赤色光 / 遠赤色光光量子束比を変化させる被覆 資材がパンジーの生育に及ぼす影響. 園学雑. 66 (別 1) : 484-485.

Wilson, S. B. and N. C. Rajapakse. 2001. Use of photoselective plastic films to control growth of three perennial salvias. J. Appl. Hort. 3: 71-74.

Yamazaki, H., R. Oi, M. Hamano, Y. Yamato and H. Miura. 2000. Inhibition of bulb development of Allium wakegi Araki by covering with far-red-intercepting film in summer. J. Japan. Soc. Hort. Sci. 69: 250-254.

横山和人・軽部 潔・松岡瑞樹・大井 龍・福田直也. 2000 . 遠赤色光遮断フィルムがプラグ育苗時の数種野菜苗質 に及ぼす影響. 筑波大農林研報. 13:23-34. 